\title{
Impaired Crosstalk Between Insulin and Glucagon Secretion in Patients With Type 2 Diabetes
}

\author{
Hidekatsu Yanai
}

In this issue (P6), Morimitsu and Hamasaki report that once-weekly glucagon-like peptide-1 (GLP-1) receptor agonist, dulaglutide ameliorated glycemic control by suppressing fasting and postprandial glucagon secretion in a patient with type 2 diabetes [1]. Their report reminded me a significance of impaired crosstalk between insulin and glucagon secretion in patients with type 2 diabetes.

In normal individuals, serum glucagon falls after carbohydrate ingestion. In diabetic patients, serum glucagon is not suppressed by carbohydrate ingestion despite hyperglycemia [2]. An inverse relationship between insulin and glucagon secretion observed in normal individuals has been lost in patients with type 2 diabetes [3]. Such an impaired crosstalk between insulin and glucagon secretion was also observed in pre-diabetic individuals [4]. Postprandial hyperglucagonemia in type 2 diabetes is likely due to loss of intra-islet postprandial suppression of glucagon secretion by insulin [5]. Therefore, altered insulin-to-glucagon ratio which was used in the report by Morimitsu and Hamasaki should play an important role in the pathophysiology of type 2 diabetes [6].

GLP-1 receptor agonist improved glycemic control by amelioration of insulin-to-glucagon ratio. Effects of other anti-diabetic drugs on insulin-to-glucagon ratio should be studied in the future.

\section{Conflict of Interest}

The author declares that he has no conflict of interest concerning this article.

\section{References}

1. Morimitsu S, Hamasaki H. Improved glycemic control due to reduction in glucagon levels by the administration of once-weekly dulaglutide in a non-obese patient with type 2 diabetes. J Endocrinol Metab;2018;8(1):69.

2. Muller WA, Faloona GR, Aguilar-Parada E, Unger RH. Abnormal alpha-cell function in diabetes. Response to carbohydrate and protein ingestion. N Engl J Med. 1970;283(3):109-115.

3. Menge BA, Gruber L, Jorgensen SM, Deacon CF, Schmidt WE, Veldhuis JD, Holst JJ, et al. Loss of inverse relationship between pulsatile insulin and glucagon secretion in patients with type 2 diabetes. Diabetes. 2011;60(8):21602168.

4. Rohrer S, Menge BA, Gruber L, Deacon CF, Schmidt WE, Veldhuis JD, Holst JJ, et al. Impaired crosstalk between pulsatile insulin and glucagon secretion in prediabetic individuals. J Clin Endocrinol Metab. 2012;97(5):E791795.

5. Meier JJ, Kjems LL, Veldhuis JD, Lefebvre P, Butler PC. Postprandial suppression of glucagon secretion depends on intact pulsatile insulin secretion: further evidence for the intraislet insulin hypothesis. Diabetes. 2006;55(4):1051-1056.

6. Jiang G, Zhang BB. Glucagon and regulation of glucose metabolism. Am J Physiol Endocrinol Metab. 2003;284(4):E671-678. 